\title{
miR-135a Protects Dextran Sodium Sulfate-Induced Inflammation in Human Colorectal Cell Lines by Activating STAT3 Signal
}

\author{
Jingru Zhang ${ }^{\mathrm{a}}$ Bo Lian ${ }^{\mathrm{b}}$ Yan Shang ${ }^{\mathrm{b}}$ Chun Li ${ }^{\mathrm{a}} \quad$ Qingkai Meng \\ ${ }^{a}$ Department of Gynaecology, Cancer Hospital of China Medical University, Liaoning Cancer Hospital \\ \& Institute, Shenyang, 'Department of colorectal surgery, Cancer Hospital of China Medical University, \\ Liaoning Cancer Hospital \& Institute, Shenyang, China
}

\section{Key Words}

miR-135a $\cdot$ Inflammation $\cdot$ STAT3

\begin{abstract}
Background/Aims: miR-135a is reduced in several cancers and has been suggested to mediate immune and inflammatory responses. However, the effect of miR-135a on inflammatory bowel diseases was obscure. This study firstly attempted to investigate the hypothesis that miR-135a alleviates dextran sodium sulfate (DSS)-induced inflammation in colonic cells and potential mechanisms are also studied. Methods: Caco-2 and HT-29 cells in this study were treated with DSS, miR-135a mimic, and S3I-201, and then CKK-8 assay was used to test cell viability. Expressions of miR-135a, cytokines, and signal transducers and activators of transcription factors (STATs) were determined by RT-PCR. Also, cytokine productions were further tested by using ELISA kits. Activation or inactivation of STAT3 signal was validated by western blotting analysis. Results: The results showed that DSS markedly downregulated miR-135a expression $(P<0.05)$ and induced inflammatory response in Caco-2 and HT-29

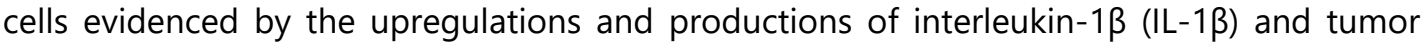
necrosis factor-a (TNF- $\mathrm{a})(\mathrm{P}<0.05)$. Transfection with miR-135a mimic significantly alleviated DSS-induced upregulations and productions of IL-1 $\beta$ and TNF- $a$ in Caco- 2 and HT-29 cells $(\mathrm{P}<0.05)$. STATs were analyzed and miR-135a mimic treatment reversed STAT3 downregulation in DSS-challenged Caco-2 and HT-29 cells compared with the mimic control $(P<0.05)$. Also, STAT3 phosphorylation was inhibited in DSS-challenged Caco-2 cells and miR-135a mimic activated STAT3 signal $(\mathrm{P}<0.05)$. S3I-201, an inhibitor of STAT3 signal, further used to inactivate STAT3 signal and the results showed that S3I-201 blocked the anti-inflammatory effect of miR135a mimic on Caco-2 and HT-29 cells evidenced by the lowered expressions and productions of proinflammatory cytokines (IL-1 $\beta$ and TNF-a) $(P<0.05)$. Conclusion: Our results indicated that miR-135a alleviated DSS-induced inflammation and activated STAT3 signal in colonic cells. Inhibition of STAT3 reversed the anti-inflammatory function of miR-135a by regulating

\footnotetext{
Qingkai Meng

Dept. of Colorectal Surgery, Cancer Hospital of China Med. Univ., Liaoning Cancer Hospital \& Institute

No. 44 Xiaoheyan Road, Dadong District, Shenyang 110042, Liaoning Province (China)

E-Mail mengqkmed@yeah.net
}

\section{KARGER}


proinflammatory cytokines. Thus, STAT3 signal might serve, at least in part, as the potential mechanism of miR-135a-mediated anti-inflammatory effect in colonic cells.

(C) 2018 The Author(s)

Published by S. Karger AG, Basel

\section{Introduction}

Inflammatory bowel diseases (IBD) include Crohn disease, ulcerative colitis, and IBDunspecified and have been considered as immune mediated chronic inflammatory disorders of the gastrointestinal tract [1-2]. Although the pathological mechanisms are multifactorial, such as environmental, genetic, immune mediated, and gut microbial factors, the main targets of therapy focus on colonic inflammation $[1,3,4]$. Cytokines play an important role in the pathogenesis of IBD by mediating multiple aspects of the inflammatory response [5-8]. Thus, targeting cytokines balance has resulted in the development of multiple biological agents in IBD. Also, cytokine-mediated activation of signal transducers and activators of transcription factor (STAT) 3 in the epithelial lining cells has been reported to improve cellular protection, survival, and proliferation in IBD models, including dextran sodium sulfate (DSS) colitis model [9-11]. Compared with other chemicals-induced experimental models, DSS serves as a direct chemical toxin to colonic epithelium leading to epithelial cell injury and the DSS model has been widely used in IBD research due to its rapidity, simplicity, reproducibility and controllability [12].

MicroRNAs (miRNAs) are small endogenous RNA molecules and serve as an important family of transcriptional and post-transcriptional regulators for gene expression [1317]. In recent decades, various bio-functions of miRNAs have been identified, such as cell proliferation and differentiation, metabolism, inflammation, oxidative stress, and tumor biology $[18,19]$. Altered concentrations or dysfunctions of miRNAs are highly associated with the development of IBD [20]. A number of miRNAs are highly associated with the initiation, development, and progression of IBD, but some also exert anti-inflammatory effect and may have the potential to be used as therapeutic targets [21, 22], such as miR-135a. Previous studies indicated that miR-135a abundance was dramatically reduced in diseases and tumor tissues $[23,24]$, suggesting a novel therapeutic potential in diseases, especially for cancers. For example, miR-135a has been evaluated to predict lymph node metastasis and tumor stage in gastric cancer [25] and acts as a tumor suppressor in gastric cancer through targeting Kinesin family member C1 [26]. In inflammatory diseases, intranasal administration of lentiviral miR-135a strongly inhibited the infiltration of eosinophils and mast cells into the nasal mucosa via influencing GATA binding protein 3 and the balance of Th1 and Th2 cells [27]. Although previous studies suggested an anti-inflammatory effect of miR-135a in cancer and nasal inflammation, the effect of miR-135a on IBD model was obscure. Thus, in this study, we firstly investigated the protective effects of miR-135a on DSSinduced inflammation in the human epithelial colorectal cell lines Caco-2 and HT-29. Both Caco-2 and HT-29 cells are isolated from colon adenocarcinomas and have been widely used for in vitro attachment and mechanistic studies [28]. The Caco- 2 cell line is characterized by the polarized monolayers in culture and differentiation with high homology to enterocytes in the intestinal epithelium, while HT-29 cells in culture are heterogeneous containing a small proportion of mucus-secreting cells and columnar absorptive cells [28]. To our knowledge, this is a first study to investigate the effects of miR-135a on two colorectal cell lines.

\section{Materials and Methods}

\section{Cell lines and cell culture}

Caco-2 and HT-29 cells (two of human epithelial colorectal cell lines) were provided by the cell bank of Chinese Academy of Sciences and were seeded in Dulbecco's modified Eagle medium (DMEM)/F12 or RPMI 1640 medium added with 10\% FBS (HyClone, Logan, UT) and $50 \mathrm{U} / \mathrm{mL}$ penicillin-streptomycin. Cells maintained at $37^{\circ} \mathrm{C}$ in a humidified chamber of $5 \% \mathrm{CO}_{2}$. Confluent cells (75-90\%) were treated with $2 \%$ DSS 


\section{Cellular Physiology Cell Physiol Biochem 2018;51:1001-1012 \begin{tabular}{ll|l} 
and Biochemistry Published onlıne: 24 November 2018 & $\begin{array}{l}\text { (c) } 2018 \text { The Author(s). Published by S. Karger AG, Basel } \\
\text { www.karger.com/cpb }\end{array}$ \\
\hline
\end{tabular}

for 4 days to establish inflammatory model $[29,30] .100$ $\mu \mathrm{M}$ S3I-201, an inhibitor of STAT3, was purchased from Calbiochem (La Jolla, CA, USA) and incubated for $1 \mathrm{~h}$ prior to DSS treatment [31]. The culture medium was renewed every 2 or $3 \mathrm{~d}$.

\section{Transfection of miRNA}

Chemically modified double-stranded RNAs designed to mimic the endogenous miR-135a and negative control miRNA (mimic NC) were all brought from Genepharma (Shanghai, China). Cells were seeded in 6-well plates and transfected at 60-70\% confluence with miR-135a mimic or the mimic NC using Lipofectamine 2000 (Invitrogen, Carlsbad, CA, USA) according to the manufacturer's instructions [30]. After transfection for $48 \mathrm{~h}$, the transfected cells were treatment with $2 \%$ DSS or S3I-201 for 4 days for further assays.
Table 1. Primers used in this study

\begin{tabular}{lc}
\hline Genes & Nucleotide sequence of primers $\left(5^{\prime}-3^{\prime}\right)$ \\
\hline \multirow{2}{*}{$\beta$-Actin } & F: CCGTTGCCTGAGGCTCTTT \\
& R: CCTTCTGCATCCTGTCAGCA \\
IL-1 $\beta$ & F: CAGAAGTACCTGAGCTCGCC \\
& R: AGATTCGTAGCTGGATGCCG \\
IL-10 & F: TGTTCTTTGGGGAGCCAACA \\
& R: GGGCTCCCTGGTTCTCTTC \\
TNF- $\alpha$ & F: CTGGGCAGGTCTACTTTGGG \\
& R: CTGGAGGCCCCAGTTTGAAT \\
STAT1 1 & F: CCGTGGCACTGCATACAATC \\
& R: ACCATGCCGAATTCCCAAAG \\
STAT3 & F: CATCCTGAAGCTGACCCAGG \\
& R: TCCTCACATGGGGGAGGTAG \\
STAT6 & F: GGGACCTGGGTAGAAGGAGA \\
& R: CTGTAGCTCTGTCCAGCGAG \\
miR-135a & F: TATGGCTTTTTATTCCTATGTGA \\
& R: TATGGCTTTTCATTCCTATGTGA \\
U6 & F: CTCGCTTCGGCAGCACA \\
& R: AACGCTTCACGATTTGCGT \\
\hline
\end{tabular}

\section{Cell viability}

Cell viability was determined using the CKK-8 assay (Sigma-Aldrich). Briefly, cells dispersed evenly in medium were seeded in a 96-well plate with a density of $1 \times 10^{4}$ cells/well. Next day, cells were treated with various concentrations of DSS, miR-135a mimic, and the negative control for 4 days. Then, CKK- 8 solution was added to each well, followed by a $2 \mathrm{~h}$ incubation. The optical density (OD) in $570 \mathrm{~nm}$ was measured by a BioTek multilabel counter. The cell proliferation inhibition index was calculated according to the formula: $\left(\mathrm{OD}_{\text {control }}-\mathrm{OD}_{\text {treatment }} / \mathrm{OD}_{\text {control }}\right) \times 100 \%$. The result was normalized according to the value of the control at day 4.

\section{ELISA kits}

The culture supernatant was collected. Cellular abundances of IL-1 $\beta$ (CSB-E08053h), IL-10 (CSBE04593h), and TNF- $\alpha$ (CSB-E04740h) were tested in the medium by ELISA kits (CUSABIO, Wuhan, China) according to the manufacturer's instructions and signals detected at $450 \mathrm{~nm} \mathrm{[32].}$

\section{Real-time PCR}

Inflammatory cytokines (IL-1 $\beta$, IL-10, and TNF-a) were determined by real-time PCR. Approximately $1 \times 10^{6}$ cells $/ \mathrm{mL}$ cells from each group were collected from six-well plates for RNA extraction and DNA synthesis according to kits (TAKARA). The gene sequences were used to design primers and synthesized by Invitrogen (Table 1). Double-distilled water was used instead of template as a negative control. The number of $\beta$-actin transcripts was used as a reference of endogenous RNA, and the quantification of test genes for each sample was standardized relative to the number of $\beta$-actin transcripts. miR-135a expression was normalized according to the abundance of U6. The $2^{-\Delta \Delta C t}$ cycle threshold formula was used to calculate the relative abundance of transcripts.

\section{Western blot}

Total proteins from $10-\mathrm{cm}$ dishes $\left(10^{6-7}\right.$ cells) were extracted using protein extraction reagents (Thermo Fisher Scientific Inc., Waltham, MA, USA). Proteins samples were quantified by BCA Protein Assay Kit (Beyotime, Jiangsu, China) and denaturated with SDS-PAGE Sample Loading Buffer (Beyotime, Jiangsu, China). 30-50 ug proteins were separated by a reducing SDS-PAGE electrophoresis. Then the proteins were transferred onto a PVDF membrane (Millipore, MA, USA) and blocked with 5\% non-fat milk in Tris-Tween buffered saline buffer for 1.5 hour. Anti-beta Actin antibody [Abcam 8226], Anti-STAT3 antibody [EPR787Y] (ab68153), and Anti-STAT3 (phospho S727) antibody (ab30647) were incubated overnight at $4^{\circ} \mathrm{C}$ and the HRP-conjugated secondary antibodies were subsequently incubated for 2 hours at room temperature. Then the membrane developed the blots using Alpha Imager 2200 software (Alpha Innotech Corporation, CA, USA). We digitally quantified the resultant signals and normalized the data to $\beta$-actin. 


\section{Cellular Physiology Cell Physiol Biochem 2018;51:1001-1012 \begin{tabular}{ll|l} 
and Biochemistry & $\begin{array}{l}\text { DOI: 10.1159/000495481 } \\
\text { Published onlIne: } 24 \text { November } 2018\end{array}$ & $\begin{array}{l}\text { (c) } 2018 \text { The Author(s). Published by S. Karger AG, Basel } \\
\text { www.karger.com/cpb }\end{array}$
\end{tabular}

\section{Statistical analysis}

All data were analyzed by SPSS 17.0 software. Difference was tested by student's T test. Data are expressed as the mean \pm standard error of mean $(\mathrm{SEM})$. Values in the same row with * are significant $(\mathrm{P}<$ $0.05)$.

\section{Results}

DSS inhibited miR-135a expression and induced inflammation in Caco-2 and HT-29 cells

DSS exposure markedly inhibited cell viability at day 3 and 4 compared with the control group in Caco-2 cells $(\mathrm{P}<0.05)$ (Fig. 1A). Expressions of miR-135a, IL-1 $\beta$, IL-10, and TNF-a were determined via RT-PCR to test the inflammatory response after DSS exposure and the results showed that DSS treatment significantly downregulated miR-135a expression in Caco-2 cells $(\mathrm{P}<0.05)$ (Fig. 1B). Also, DSS-challenged Caco-2 cells exhibited marked inflammatory response evidenced by the upregulations of IL-1 $\beta$ and TNF- $a$ in the DSS group (Fig. 1C and E) $(\mathrm{P}<0.05)$. Meanwhile, the expression of IL-10, an anti-inflammatory cytokine, was upregulated in DSS challenged-Caco-2 cells $(\mathrm{P}<0.05)$ (Fig. 1D).

DSS-treated HT-29 cells exhibited similar results that DSS exposure reduced cell viability at day $4(\mathrm{P}<0.05)$ (Fig. $1 \mathrm{~F})$ and downregulated miR-135a expression $(\mathrm{P}<0.05)$ (Fig. $1 \mathrm{G})$ compared with the control HT-29 cells. In addition, DSS treatment markedly increased cellular mRNA abundances of IL-1 $\beta$ and TNF-a $(\mathrm{P}<0.05)$ (Fig. $1 \mathrm{H}$ and $\mathrm{K})$.

Fig. 1. Effects of DSS on cell viability, miR-135a and cytokine expressions in Caco-2 and HT-29 cells. (A) cell viability (\%) in Caco-2 cells (n=8); (B) miR-135a expression in Caco-2 cells $(\mathrm{n}=4) ; \quad(\mathrm{C}) \quad$ IL-1 $\beta$ mRNA abundance in Caco-2 cells $(\mathrm{n}=4) ; \quad$ (D) IL-10 mRNA abundance in Caco-2 cells $(\mathrm{n}=4) ;$ (E) TNF-a mRNA abundance in Caco-2 cells $(n=4)$. (F) cell viability (\%) in HT-29 cells $(n=8) ;(G)$ miR-135a expression in HT-29 cells ( $n=4) ;(H)$ IL-1 $\beta$ mRNA abundance in HT-29 cells ( $\mathrm{n}=4)$; (J) IL-10 mRNA abundance in HT-29 cells $(\mathrm{n}=4) ; \quad(\mathrm{K})$ TNF-a mRNA abundance in HT-29 cells $(\mathrm{n}=4)$.Data are expressed as the mean \pm SEM. * means the difference was significant $(\mathrm{P}<0.05) . \quad \mathrm{DSS}$, dextran sodium sulfate; IL-1 $\beta$, interleukin-1 $\beta$; IL10, interleukin-10; TNF-a, tumor necrosis factor-a.
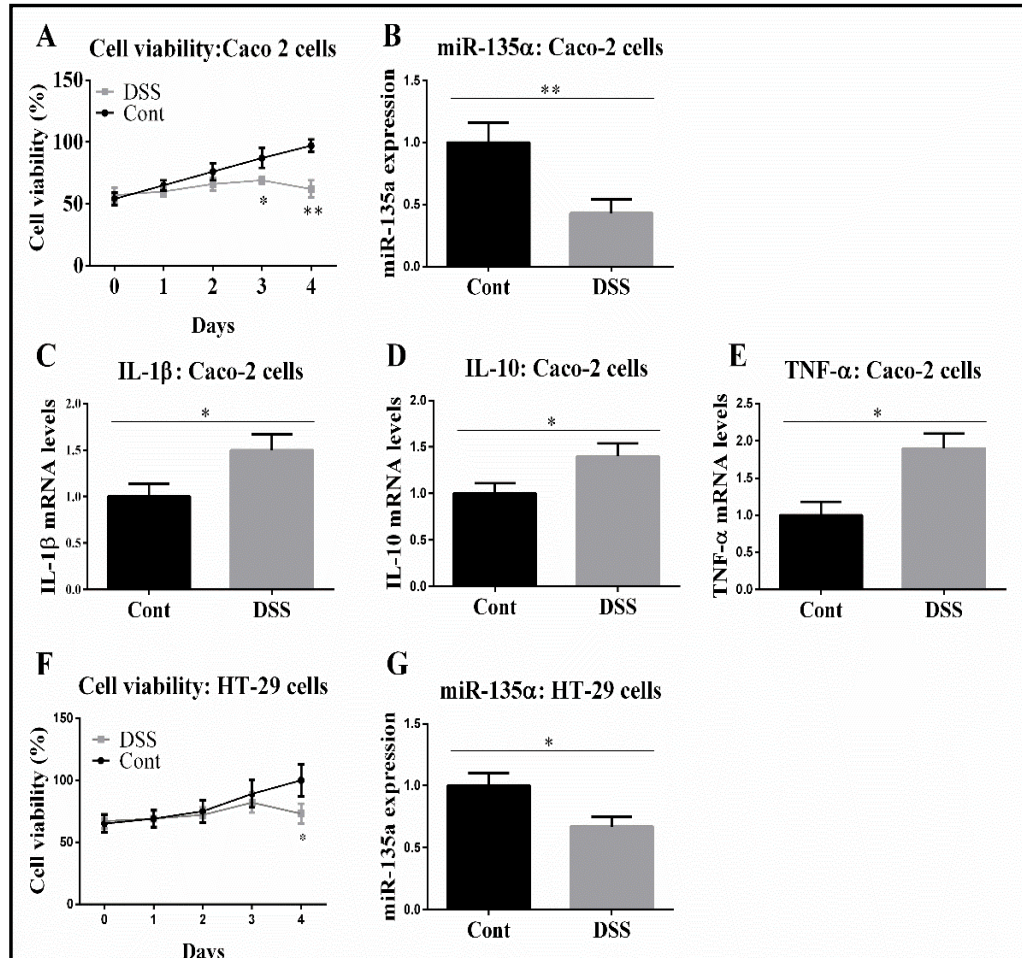

G miR-135 $\alpha$ : HT-29 cells
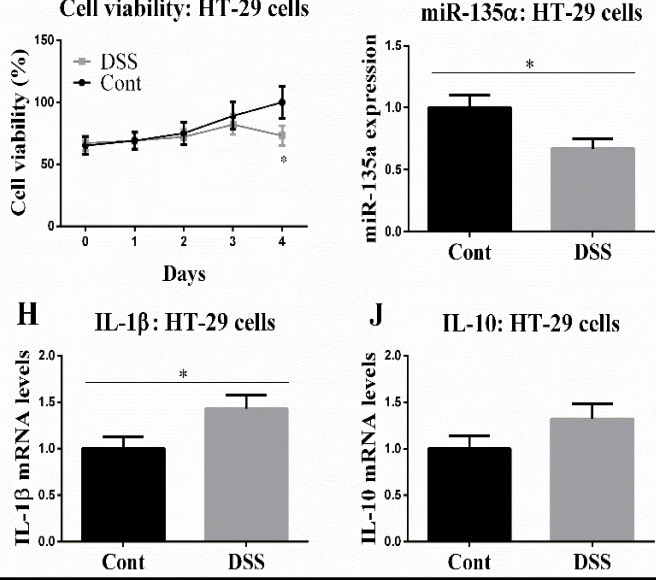

K TNF- $\alpha$ : HT-29 cells

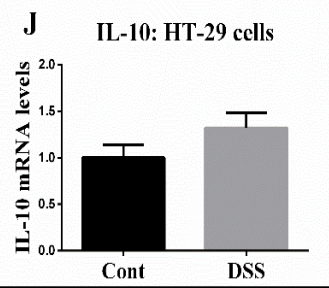

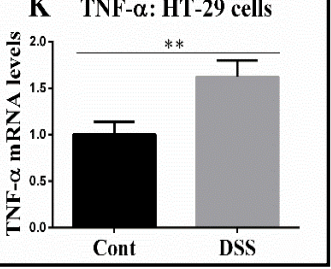


Fig. 2. Effects of miR$135 \mathrm{a}$ on cell viability and cytokine expression and production in Caco-2 and HT-29 cells $(n=4)$. (A) IL-1 $\beta$ mRNA abundance in Caco2 cells; (B) IL-10 mRNA abundance in Caco-2 cells; (C) TNF-a mRNA abundance in Caco-2 cells; (D) IL-1 $\beta$ production in Caco-2 cells; (E) IL-10 production in Caco-2 cells; (F) TNF-a production in Caco- 2 cells. (G) IL-1 $\beta$ production in HT-29 cells; (H) IL-10 production in HT-29 cells; (I) TNF-a production in HT29 cells. Data are expressed as the mean \pm SEM. * means the difference was significant $(\mathrm{P}<0.05)$. DSS, dextran sodium sulfate; IL-1 $\beta$, interleukin-1 $\beta$; IL10, interleukin-10; TNF- $a$, tumor necrosis factor-a.

Fig. 3. miR-135a mimic upregulated STAT expression in DSS-challenged Caco-2 and HT-29 cells by RT-PCR $(n=4)$. (A) STAT1 mRNA abundance in Caco-2 cells; (B) STAT3 mRNA abundance in Caco-2 cells; (C) STAT6 mRNA abundance in Caco2 cells; (D) STAT1 mRNA abundance in HT-29 cells; (E) STAT3 mRNA abundance in HT-29 cells; (F) STAT6 mRNA abundance in HT-29 cells. Data are expressed as the mean \pm SEM. ${ }^{*}$ means the difference was significant $(\mathrm{P}<0.05)$. DSS, dextran sodium sulfate; STAT, signal transducers and activators of transcription factor.
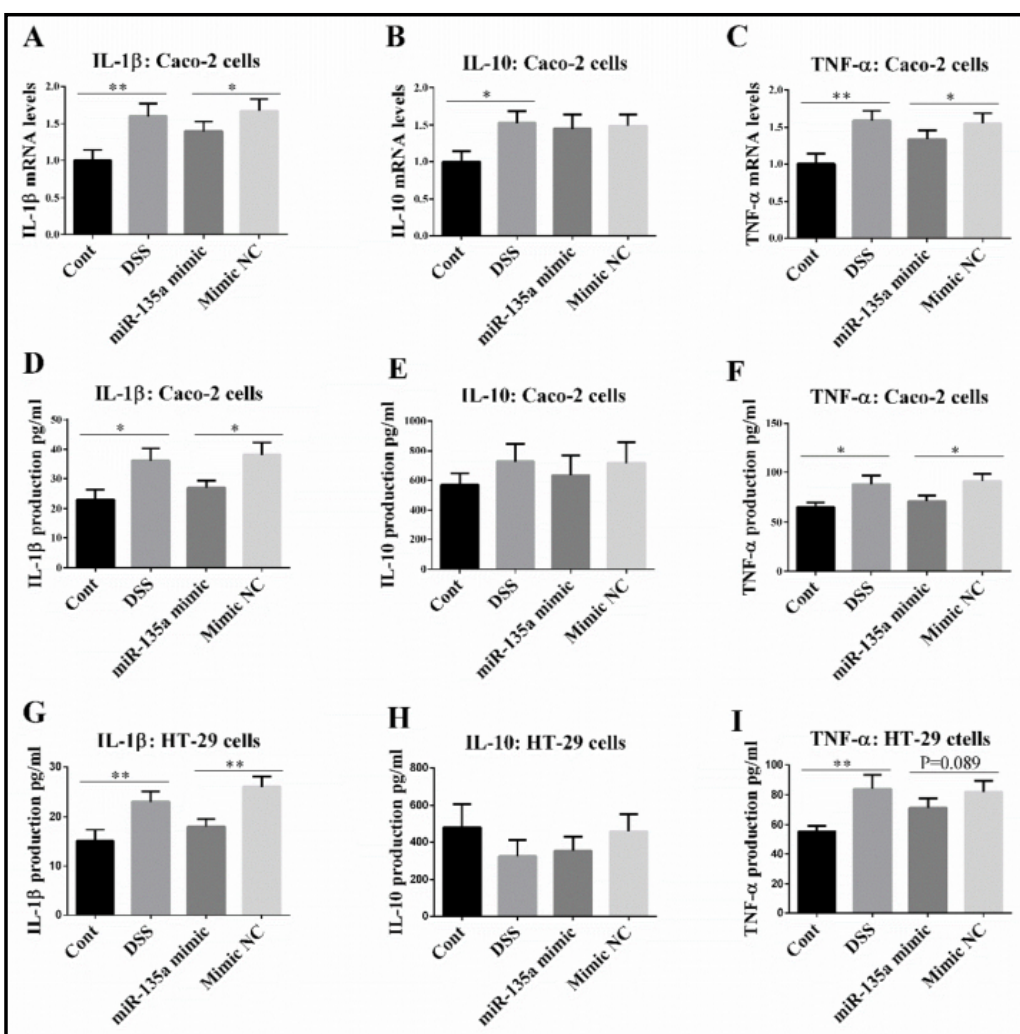

F
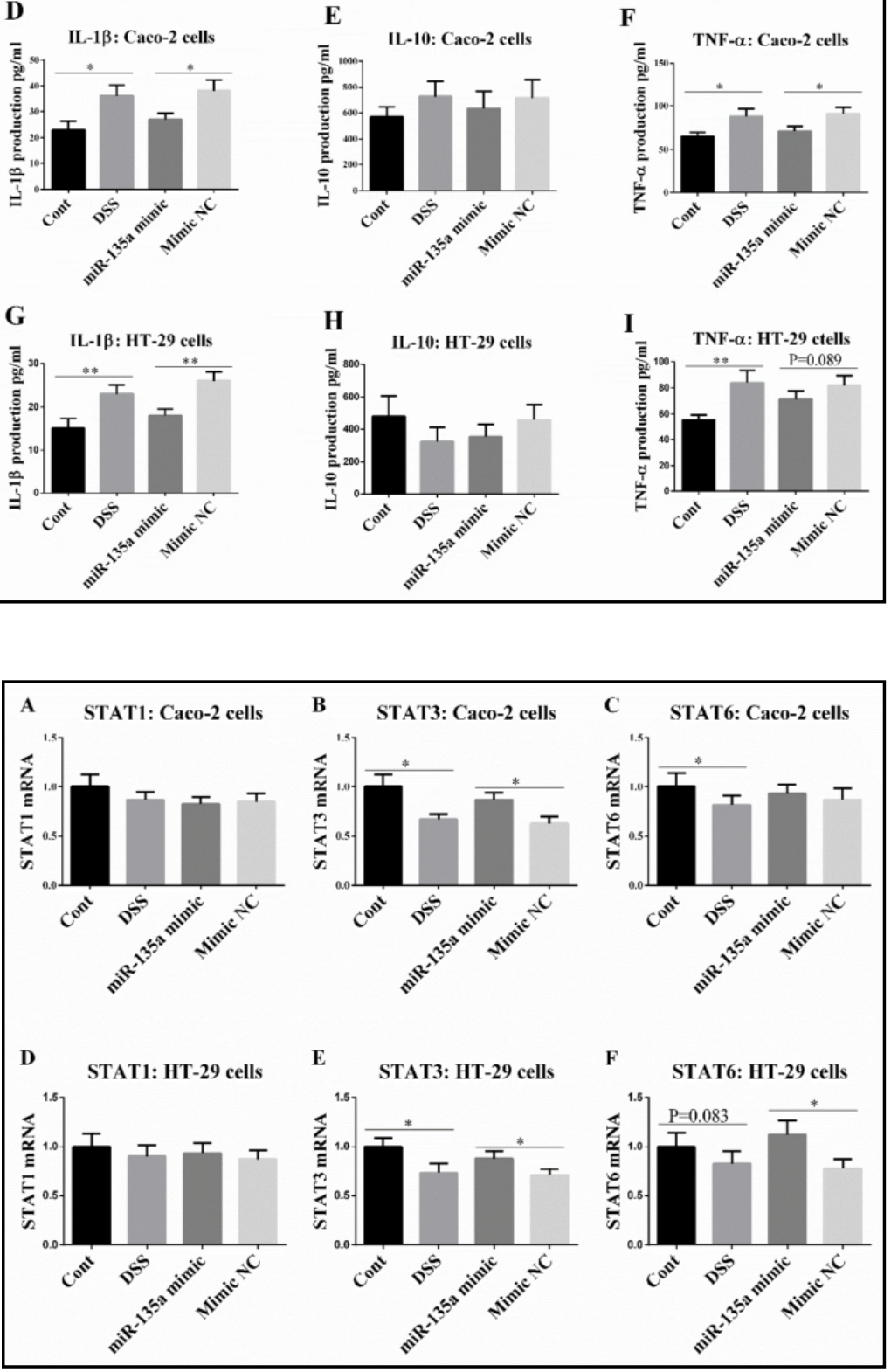
miR-135a attenuated DSS-induced inflammation in Caco-2 and HT-29 cells

miR-135a has been widely demonstrated to involve in inflammation, thus miR-135a mimic was used to investigate the effect of miR-135a on DSS-induced inflammation in Caco-2 and HT-29 cells. Compared with the negative control, miR-135a mimic treatment markedly downregulated IL- $1 \beta$ and TNF-a expressions in Caco-2 cells $(\mathrm{P}<0.05)$ (Fig. 2A and $\mathrm{C}$ ). Meanwhile, cytokine productions were determined via ELISA kits and the results showed a similar trend that miR-135a mimic alleviated IL-1 $\beta$ and TNF- $a$ abundances in the cell medium $(\mathrm{P}<0.05)$ (Fig. 2D-F).

The results were further validated in HT-29 cells (Fig. 2G-I) that miR-135a mimic markedly reversed IL-1 $\beta$ production in the DSS treated HT-29 cells $(\mathrm{P}<0.01)$. Meanwhile, TNF-a abundance tended to be decreased in the miR-135a mimic group, but the difference was insignificant $(\mathrm{P}=0.089)$. Together, these results suggested an anti-inflammatory effect of miR-135a by inhibiting the expressions and productions of proinflammatory cytokine.

miR-135a mimic activated STAT signal in Caco-2 and HT-29 cells

STATs are highly associated with the expression of proinflammatory cytokines [33]. In this study, we found that DSS exposure markedly reduced mRNA abundance of STAT3 in Caco-2 and HT-29 cells compared with the control group $(\mathrm{P}<0.05)$ (Fig. 3). Meanwhile, in DSS-challenged cells, miR-135a mimic markedly upregulated STAT3 expression compared with the inhibitor negative control $(\mathrm{P}<0.05)$ (Fig. 3).

Western blotting analysis was further used to validate the effect of miR-135a on STAT3 expression in Caco-2 cells and the results showed that DSS markedly inhibited STAT3 phosphorylation $(\mathrm{P}<0.05)$ (Fig. 4), while miR-135a mimic markedly enhanced STAT3 phosphorylation $(\mathrm{P}<0.05)$ (Fig. 4), indicating that miR-135a activated STAT3 signal in DSSchallenged cells.

STAT3 inhibition blocked the anti-inflammatory effect of miR-135a in Caco-2 and HT-29 cells

In DSS and miR-135a mimic co-treated cells, we further used S3I-201 to inhibit STAT3 signal and the results showed that S3I-201 markedly reduced STAT3 phosphorylation compared with the DSS and miR-135a mimic co-treated group $(\mathrm{P}<0.05)$ (Fig. 5).

Fig. 4. miR-135a mimic enhanced STAT phosphorylation in DSS-challenged cells by western blot $(n=4)$. (A) Ratio of STAT3 phosphorylation; (B) immunoblotting for STAT3 and p-STAT3. Data are expressed as the mean \pm SEM. * means the difference was significant $(\mathrm{P}<0.05)$. DSS, dextran sodium sulfate; STAT3, signal transducers and activators of transcription factor 3 .

Fig. 5. S3I-201 inhibited STAT3 signal in DSS and miR-135a mimic cotreated cells $(n=4)$. (A) Ratio of STAT3 phosphorylation; (B) immunoblotting for STAT3 and p-STAT3. Data are expressed as the mean \pm SEM. $*$ means the difference was significant $(\mathrm{P}<0.05)$. DSS, dextran sodium sulfate; STAT3, signal transducers and activators of transcription factor 3 .
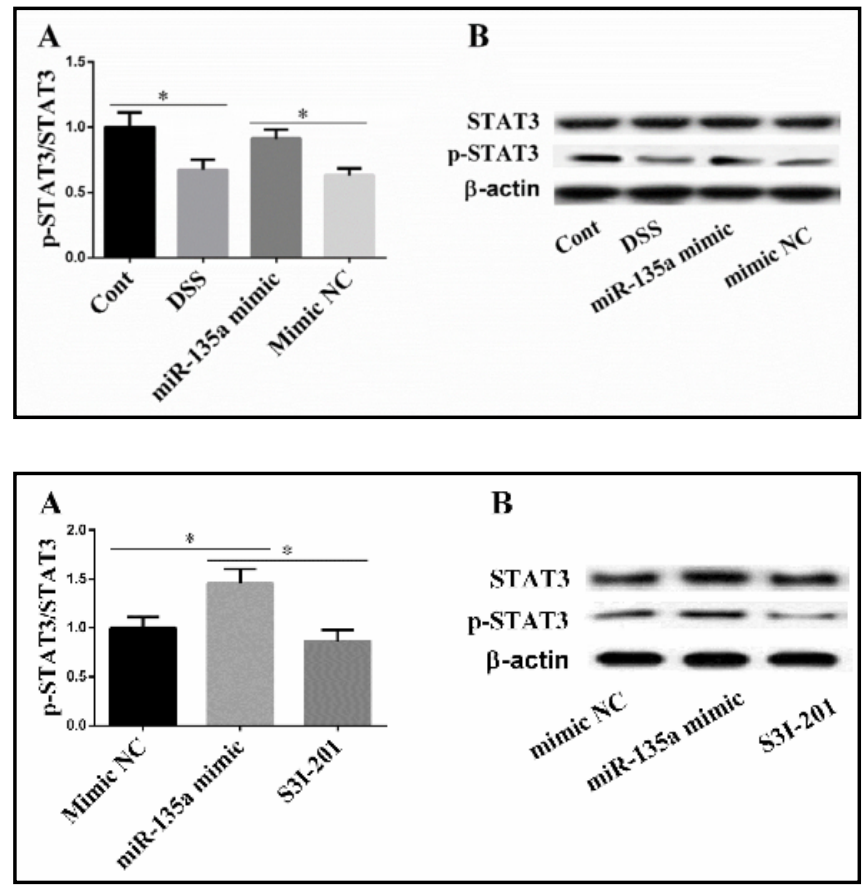


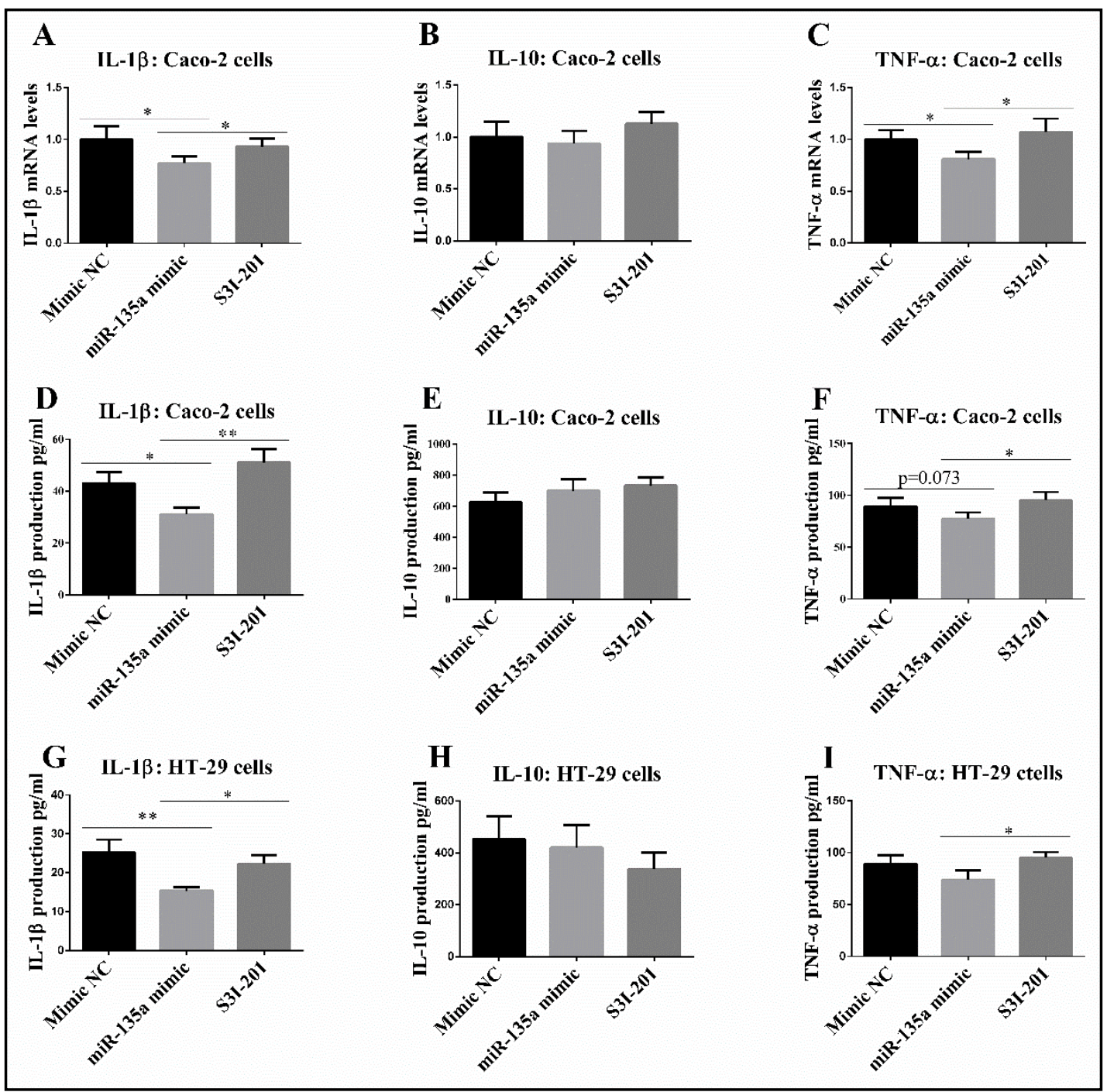

Fig. 6. Effect of S31-201 on cellular cytokine expression and production in Caco-2 and HT-29 cells ( $n=4)$. (A) IL-1 $\beta$ mRNA abundance in Caco-2 cells; (B) IL-10 mRNA abundance in Caco-2 cells; (C) TNF-a mRNA abundance in Caco-2 cells; (D) IL-1 $\beta$ production in Caco-2 cells; (E) IL-10 production in Caco-2 cells; (F) TNF-a production in Caco-2 cells; (G) IL-1 $\beta$ production in HT-29 cells; (H) IL-10 production in HT-29 cells; (I) TNF-a production in HT-29 cells. Data are expressed as the mean \pm SEM. * means the difference was significant $(\mathrm{P}<0.05)$. DSS, dextran sodium sulfate; IL-1 $\beta$, interleukin-1 $\beta$; IL-10, interleukin-10; TNF-a, tumor necrosis factor-a.

Moreover, S3I-201 treatment markedly upregulated IL-1 $\beta$ and TNF-a expressions in DSS and miR-135a mimic co-treated Caco-2 cells $(\mathrm{P}<0.05)$ (Fig. 6$)$. The results were further confirmed via ELISA analyses that miR-135a blocked the inhibitory effect of miR-135a on IL$1 \beta$ and TNF-a productions in Caco- 2 cells $(\mathrm{P}<0.05)$ (Fig. 6). In DSS and miR-135a co-treated HT-29 cells, S3I-201 addition also increased IL-1 $\beta$ and TNF-a production $(\mathrm{P}<0.05)$ (Fig. 6), suggesting that inhibition of STAT3 blocked the beneficial effect of miR-135a on DSS-induced inflammation. 


\section{Cellular Physiology Cell Physiol Biochem 2018;51:1001-1012 and Biochemistry Published \begin{tabular}{l|l} 
DOI: 10.1159/000495481 & $\begin{array}{l}\text { (c) } 2018 \text { The Author(s). Published by S. Karger AG, Basel } \\
\text { www.karger.com/cpb }\end{array}$
\end{tabular} \\ Zhang et al.: miR-135a and Inflammation}

\section{Discussion}

miR-135a has been widely demonstrated to involve in inflammatory response and cytokines production, thus targeting miR-135a may serve as a novel therapeutic method for treating inflammatory diseases [27, 34]. In this study, we found that miR-135a was reduced in DSS-induced inflammation and miR-135a mimic alleviated DSS-induced inflammatory response and activated STAT3 signal in Caco-2 and HT-29 cells, while STAT3 antagonist (S3I201) blocked the anti-inflammatory effect, suggesting that STAT3 might serve as the potential mechanism in the anti-inflammatory role of miR-135a in DSS-induced inflammation.

IBD is chronic and inflammatory disorder primarily involving the mucosa and submucosa of the gastrointestinal tract and patients with IBD represent a major risk factor for the development of colorectal cancer [35-37]. Inflammatory response has been considered as a major characteristic of IBD and it is highly associated with the occurrence of IBD [38]. DSS has been widely used to induce inflammatory response in vivo and vitro IBD models [39-41]. In this study, DSS exposure markedly caused inflammation via upregulating expressions of proinflammatory cytokines (IL-1 $\beta$ and TNF-a) in Caco-2 cells. miR-135a has been reported to exhibit various physiological functions, such as cell proliferation, tumor biology, and immune system $[42,43]$. In this study, we found that miR-135a mimic alleviated DSS-induced inflammation by down-regulating IL- $1 \beta$ and TNF-a expressions and productions in Caco-2 and HT-29 cells. IL-1 $\beta$ and TNF- $a$ are two major mediators of the inflammatory response and generations of IL-1 $\beta$ and TNF-a precipitate acute attacks of systemic or local inflammation or chronic diseases [44-46]. Therefore, blocking proinflammatory cytokines (IL-1 $\beta$ and TNF-a) by targeting miRNA may serve as a novel potential method to treat inflammatory diseases.

STAT proteins play a central role in regulating cytokine-dependent inflammation and immunity [47-49]. 7 STATs (STAT1, STAT2, STAT3, STAT4, STAT5a, STAT5b, and STAT6) are identified and STAT3 is highly associated with inflammatory response. In response to inflammatory stress, STAT3 directly serves as a transcription factor to regulate expression of proinflammatory cytokines [50]. STAT3 activation has been widely reported to maintain epithelial homeostasis and cytokine balance [9, 51]. For example, STAT3 activation is essential to countering the deleterious consequences of sepsis on pneumonia susceptibility [52]. However, other studies also indicated a proinflammatory effect of STAT3 [53], which has been confirmed in a hyperimmunoglobulin E syndrome model that STAT3 revealed pro- and anti-inflammatory functions [54]. Several studies showed that miR-135a can target MAPK and nuclear factor-kappaB pathways [11,55-58], which might be further interacted with STAT3 signal. In this study, miR-135a mimic treatment markedly activated STAT3 signal, while inhibition of STAT3 blocked the anti-inflammatory effect. Similarly, the phosphorylation level of STAT3 signal was inhibited by the suppressor of cytokine signaling 3 along with the elevated expression of TNF- $\alpha$, whereas activation of STAT3 indicated a lowered TNF- $\alpha$ expression in 3T3-L1 adipocyte [59]. However, some reports also indicated that STAT3 activation promoted proinflammatory cytokine productions [60]. The difference may be caused by different models that the proinflammatory effect of STAT3 mainly occurs in animal models (mice and rats), while the in vitro effect of STAT3 in Caco-2 and HT-29 cells was investigated in the present study. Also, STAT3-drived negative-feedback loop may serve as the potential mechanism, which further limits the formation of pro-inflammatory cytokines [61]. Various reports have indicated that STAT3 serves as a potential target in DSSinduced mouse colitis $[62,63]$. For example, Koukos et al. reported that miRNA can mediate the expression of STAT3, which further influences inflammatory response in pediatric patients with ulcerative colitis [20]. Thus, we anticipated that STAT3 serves as the molecular mechanism in the protective effect of miR-135a inhibition on DSS-induced inflammation in vitro. 


\section{Cellular Physiology Cell Physiol Biochem 2018;51:1001-1012 \begin{tabular}{ll|l} 
and Biochemistry Published online: 24 November 2018 & $\begin{array}{l}\text { (c) } 2018 \text { The Author(s). Published by S. Karger AG, Basel } \\
\text { www.karger.com/cpb }\end{array}$ \\
\hline
\end{tabular} \\ Zhang et al.: miR-135a and Inflammation}

\section{Conclusion}

In conclusion, DSS induced inflammation by upregulating of proinflammatory cytokines (IL-1 $\beta$ and TNF-a) in Caco-2 and HT-29 cells. miR-135a mimic treatment alleviated DSSinduced inflammation by inhibiting IL-1 $\beta$ and TNF-a expressions and productions in Caco-2 and HT-29 cells. The mechanism might be associated with STAT3 signal as STAT3 inhibitor blocked the anti-inflammatory effect of miR-135a in DSS-challenged Caco-2 and HT-29 cells. However, detailed mechanisms of STAT3-mediated pro- or anti-inflammatory effects should be studied in different models. Together, our findings provided new approaches to ameliorate IBD by targeting miRNA, especially for miR-135a.

\section{Acknowledgements}

This study was supported by the project of "Liaoning clinical research center for colorectal cancer" (2015225005), National Natural Science Fund from the National Natural Science Foundation of China (81672427 and 81602407), and Liaoning BaiQianWan Talents Program" [2017] No. B44.

\section{Disclosure Statement}

The authors have declared that no competing interests exist.

\section{References}

1 Abraham BP, Ahmed T, Ali T: Inflammatory bowel disease: pathophysiology and current therapeutic approaches. Handb Exp Pharmacol 2017;239:115-146.

-2 Rademakers G, Vaes N, Schonkeren S, Koch A, Sharkey KA, Melotte V: The role of enteric neurons in the development and progression of colorectal cancer. Biochim Biophys Acta Rev Cancer 2017;1868:420-434.

-3 Barteneva NS, Baiken Y, Fasler-Kan E, Alibek K, Wang S, Maltsev N, Ponomarev ED, Sautbayeva Z, Kauanova S, Moore A, Beglinger C, Vorobjev IA: Extracellular vesicles in gastrointestinal cancer in conjunction with microbiota: On the border of Kingdoms. Biochim Biophys Acta Rev Cancer 2017;1868:372-393.

4 Puccini A, Berger MD, Naseem M, Tokunaga R, Battaglin F, Cao S, Hanna DL, McSkane M, Soni S, Zhang W, Lenz HJ: Colorectal cancer: epigenetic alterations and their clinical implications. Biochim Biophys Acta Rev Cancer 2017; 1868:439-448.

-5 Neurath MF: Cytokines in inflammatory bowel disease. Nat Rev Immunol 2014;14:329-342.

6 Levy A, Nigro G, Sansonetti PJ, Deutsch E: Candidate immune biomarkers for radioimmunotherapy. Biochim Biophys Acta Rev Cancer 2017;1868:58-68.

7 Jones VS, Huang RY, Chen LP, Chen ZS, Fu LW, Huang RP: Cytokines in cancer drug resistance: Cues to new therapeutic strategies. Biochim Biophys Acta Rev Cancer 2016;1865:255-265.

-8 Lam K, Pan K, Linnekamp JF, Medema JP, Kandimalla R: DNA methylation based biomarkers in colorectal cancer: A systematic review. Biochim Biophys Acta Rev Cancer 2016;1866:106-120.

-9 Nguyen PM, Putoczki TL, Ernst M: STAT3-activating cytokines: a therapeutic opportunity for inflammatory bowel disease? J Interferon Cytokine Res 2015;35:340-350.

10 Lee SY, Lee SH, Yang EJ, Kim JK, Kim EK, Jung K, Jung H, Lee K, Lee HH, Lee BI, Park SH, Shin DY, Cho ML: Coenzyme Q10 inhibits Th17 and STAT3 signaling pathways to ameliorate colitis in mice. J Med Food 2017;20:821-829.

11 Chae HS, You BH, Song J, Ko HW, Choi YH, Chin YW: Mangosteen extract prevents dextran sulfate sodiuminduced colitis in mice by suppressing NF-kappa B activation and inflammation. J Med Food 2017;20:727733. 


\section{Cellular Physiology Cell Physiol Biochem 2018;51:1001-1012

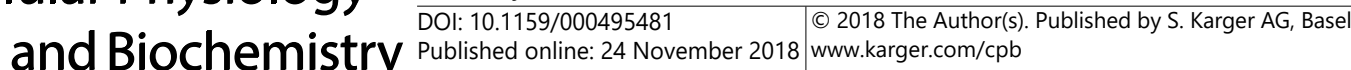

12 Eichele DD, Kharbanda KK: Dextran sodium sulfate colitis murine model: An indispensable tool for advancing our understanding of inflammatory bowel diseases pathogenesis. World J Gastroentero 2017;23:6016-6029.

13 Wilson RA, Deasy W, Hayes A, Cooke MB: High fat diet and associated changes in the expression of microRNAs in tissue: Lessons learned from animal studies. Mol Nutr Food Res DOI: 10.1002/mnfr.201600943.

$\$ 14$ Baker BC, Mackie FL, Lean SC, Greenwood SL, Heazell AEP, Forbes K, Jones RL: Placental dysfunction is associated with altered microRNA expression in pregnant women with low folate status. Mol Nutr Food Res DOI: $10.1002 / \mathrm{mnfr} .201600646$.

15 van Voss MRH, van Diest PJ, Raman V: Targeting RNA helicases in cancer: The translation trap. Biochim Biophys Acta Rev Cancer 2017;1868:510-520.

16 Terracciano D, Terreri S, de Nigris F, Costa V, Calin GA, Cimmino A: The role of a new class of long noncoding RNAs transcribed from ultraconserved regions in cancer. Biochimica Et Biochim Biophys Acta Rev Cancer 2017;1868:449-455.

17 Todorova A, Pesheva M, Iliev I, Bardarov K, Todorova T: Antimutagenic, antirecombinogenic, and antitumor effect of amygdalin in a yeast cell-based test and mammalian cell lines. J Med Food 2017;20:360-366.

18 Greenberg DS, Soreq H: MicroRNA therapeutics in neurological disease. Curr Pharm Des 2014;20:60226027.

19 Batkai S, Thum T: Analytical approaches in microRNA therapeutics. J Chromatogr B Analyt Technol Biomed Life Sci 2014;964:146-152.

-20 Koukos G, Polytarchou C, Kaplan JL, Morley-Fletcher A, Gras-Miralles B, Kokkotou E, Baril-Dore M, Pothoulakis C, Winter HS, Iliopoulos D: MicroRNA-124 regulates STAT3 expression and is down-regulated in colon tissues of pediatric patients with ulcerative colitis. Gastroenterology 2013;145:842.

-21 Cao B, Zhou X, Ma J, Zhou W, Yang W, Fan D, Hong L: Role of MiRNAs in inflammatory bowel disease. Dig Dis Sci 2017;62:1426-1438.

22 Chapman CG, Pekow J: The emerging role of miRNAs in inflammatory bowel disease: a review. Therap Adv Gastroenterol 2015;8:4-22.

-23 Shi H, Ji Y, Zhang D, Liu Y, Fang P: MiR-135a inhibits migration and invasion and regulates EMT-related marker genes by targeting KLF8 in lung cancer cells. Biochem Biophys Res Commun 2015;465:125-130.

24 Mao XP, Zhang LS, Huang B, Zhou SY, Liao J, Chen LW, Qiu SP, Chen JX: Mir-135a enhances cellular proliferation through post-transcriptionally regulating PHLPP2 and FOXO1 in human bladder cancer. J Transl Med 2015;13:

-25 Liu L, Ye JX, Qin YZ, Chen QH, Ge LY: Evaluation of miR-29c, miR-124, miR-135a and miR-148a in predicting lymph node metastasis and tumor stage of gastric cancer. Int J Clin Exp Med 2015;8:22227-22236.

26 Zhang CL, Chen XQ Chen XJ, Wang XT, Ji AY, Jiang LF, Sang F, Li FC: miR-135a acts as a tumor suppressor in gastric cancer in part by targeting KIFC1. Oncotargets Ther 2016;9:3555-3563.

27 Deng YQ, Yang YQ Wang SB, Li F, Liu MZ, Hua QQ, Tao ZZ: Intranasal administration of lentiviral miR-135a regulates mast cell and allergen-induced inflammation by targeting GATA-3. Plos One 2015;10: e0139322.

-28 Gagnon M, Berner AZ, Chervet N, Chassard C, Lacroix C: Comparison of the Caco-2, HT-29 and the mucussecreting HT29-MTX intestinal cell models to investigate Salmonella adhesion and invasion. J Microbiol Meth 2013;94:274-279.

29 Nighot P, Young K, Nighot M, Rawat M, Sung EJ, Maharshak N, Plevy SE, Ma T, Blikslager A: Chloride channel ClC-2 is a key factor in the development of DSS-induced murine colitis. Inflamm Bowel Dis 2013;19:28672877.

30 Samak G, Chaudhry KK, Gangwar R, Narayanan D, Jaggar JH, Rao R: Calcium/Ask1/MKK7/JNK2/c-Src signalling cascade mediates disruption of intestinal epithelial tight junctions by dextran sulfate sodium. Biochem J 2015;465:503-515.

-31 Bu LL, Li YC, Yu GT, Liu JF, Deng WW, Zhang WF, Zhang L, Sun ZJ: Targeting phosphorylation of STAT3 delays tumor growth in HPV-negative anal squamous cell carcinoma mouse model. Sci Rep 2017;7:6629.

-32 Li C, Lun W, Zhao X, Lei S, Guo Y, Ma J, Zhi F: Allicin alleviates inflammation of trinitrobenzenesulfonic acidinduced rats and suppresses P38 and JNK pathways in Caco-2 cells. Mediators Inflamm 2015;2015:434692.

-33 Tsunekawa T, Banno R, Mizoguchi A, Sugiyama M, Tominaga T, Onoue T, Hagiwara D, Ito Y, Iwama S, Goto M, Suga H, Sugimura Y, Arima H: Deficiency of PTP1B attenuates hypothalamic inflammation via activation of the JAK2-STAT3 pathway in microglia. EBioMedicine 2017;16:172-183. 


\section{Cellular Physiology Cell Physiol Biochem 2018;51:1001-1012 and Biochemistry \begin{tabular}{l|l} 
DOI: $10.1159 / 000495481$ & $\begin{array}{l}\text { C } 2018 \text { The Author(s). Published by S. Karger AG, Basel } \\
\text { www.karger.com/cpb }\end{array}$
\end{tabular} \\ Zhang et al.: miR-135a and Inflammation}

34 Palmer CS, Dehart M, Zhang X, Feilotter H, Lloyd A, Zekry A: miR-135a plays a key role in regulating lipogenesis and inflammation in liver diseases. J Gastroen Hepatol 2010;25:A128-A128.

-35 Falcone EL, Abusleme L, Swamydas M, Lionakis MS, Ding L, Hsu AP, Zelazny AM, Moutsopoulos NM, Kuhns DB, Deming C, Quinones M, Segre JA, Bryant CE, Holland SM: Colitis susceptibility in p47(phox-/-) mice is mediated by the microbiome. Microbiome 2016;4:13.

-36 Park BK, Chun E, Choi JJ, Shin Y, Kho YT, Oh SH, Kim SY, Lee TH, Kim TW, Shin E, Do SG, Jin M: Administration of wasabia koreana ameliorates irritable bowel syndrome-like symptoms in a zymosaninduced mouse model. J Med Food 2017;20:474-484.

-37 Seo H, Oh J, Hahn D, Kwon CS, Lee JS, Kim JS: Protective effect of glyceollins in a mouse model of dextran sulfate sodium-induced colitis. J Med Food 2017;20:1055-1062.

38 Sanchez-Fidalgo S, Cardeno A, Sanchez-Hidalgo M, Aparicio-Soto M, de la Lastra CA: Dietary extra virgin olive oil polyphenols supplementation modulates DSS-induced chronic colitis in mice. J Nutr Biochem 2013;24:1401-1413.

39 Martinez Gomez JM, Chen L, Schwarz H, Karrasch T: CD137 facilitates the resolution of acute DSS-induced colonic inflammation in mice. PLoS One 2013;8:e73277.

40 Shi C, Liang Y, Yang J, Xia Y, Chen H, Han H, Yang Y, Wu W, Gao R, Qin H: MicroRNA-21 knockout improve the survival rate in DSS induced fatal colitis through protecting against inflammation and tissue injury. PLoS One 2013;8:e66814.

41 Kang SH, Jeon YD, Moon KH, Lee JH, Kim DG, Kim W, Myung H, Kim JS, Kim HJ, Bang KS, Jin JS: Aronia berry extract ameliorates the severity of dextran sodium sulfate-induced ulcerative colitis in mice. J Med Food 2017;20:667-675.

42 Zhou HD, Guo WJ, Zhao YJ, Wang YF, Zha RP, Ding J, Liang LH, Yang GH, Chen ZY, Ma BJ, Yin BB: MicroRNA135 a acts as a putative tumor suppressor by directly targeting very low density lipoprotein receptor in human gallbladder cancer. Cancer Sci 2014;105:956-965.

43 Dang Z, Xu WH, Lu P, Wu N, Liu J, Ruan B, Zhou L, Song WJ, Dou KF: MicroRNA-135a inhibits cell proliferation by targeting Bmi1 in pancreatic ductal adenocarcinoma. Int J Bio Sci 2014;10:733-745.

44 Dinarello CA: A clinical perspective of IL-1 beta as the gatekeeper of inflammation. Eur J Immunol 2011;41:1203-1217.

45 Voronov E, Apte RN: IL-1 in colon inflammation, colon carcinogenesis and invasiveness of colon cancer. Cancer Microenviron 2015;8:187-200.

46 Joo HK, Choi S, Lee YR, Lee EO, Park MS, Lim YP, Park JT, Jeon BH: Ethanol extract of brassica rapa ssp pekinensis suppresses tumor necrosis factor-alpha-induced inflammatory response in human umbilical vein endothelial cells. J Med Food 2017;20:511-518.

47 Yu H, Pardoll D, Jove R: STATs in cancer inflammation and immunity: a leading role for STAT3. Nat Rev Cancer 2009;9:798-809.

-48 Villarino AV, Kanno Y, Ferdinand JR, O’Shea JJ: Mechanisms of Jak/STAT signaling in immunity and disease. J Immunol 2015;194:21-27.

49 Gu MY, Chun YS, Zhao D, Yong RS, Yang HO: Glycyrrhiza uralensis and semilicoisoflavone B reduce abeta secretion by increasing PPARgamma expression and inhibiting STAT3 phosphorylation to inhibit BACE1 expression. Mol Nutr Food Res DOI:10.1002/mnfr.201700633

50 He G, Karin M: NF-kappaB and STAT3 - key players in liver inflammation and cancer. Cell Res 2011;21:159168.

-51 Nguyen AV, Wu YY, Liu Q, Wang D, Nguyen S, Loh R, Pang J, Friedman K, Orlofsky A, Augenlicht L, Pollard JW, Lin EY: STAT3 in epithelial cells regulates inflammation and tumor progression to malignant state in colon. Neoplasia 2013;15:998-1008.

\$52 Hilliard KL, Allen E, Traber KE, Kim Y, Wasserman GA, Jones MR, Mizgerd JP, Quinton LJ: Activation of hepatic STAT3 maintains pulmonary defense during endotoxemia. Infect Immun 2015;83:4015-4027.

53 Ma JQ, Ding J, Xiao ZH, Liu CM: Ursolic acid ameliorates carbon tetrachloride-induced oxidative DNA damage and inflammation in mouse kidney by inhibiting the STAT3 and NF-kappa B activities. Int Immunopharmacol 2014;21:389-395.

-54 Steward-Tharp SM, Laurence A, Kanno Y, Kotlyar A, Villarino AV, Sciume G, Kuchen S, Resch W, Wohlfert EA, Jiang K, Hirahara K, Vahedi G, Sun HW, Feigenbaum L, Milner JD, Holland SM, Casellas R, Powrie F, O’Shea JJ: A mouse model of HIES reveals pro- and anti-inflammatory functions of STAT3. Blood 2014;123:29782987. 


\section{Cellular Physiology Cell Physiol Biochem 2018;51:1001-1012 \begin{tabular}{ll|l} 
DOl: 10.1159/000495481 & 2018 The Author(s). Published by S. Karger AG, Basel \\
and Biochemistry & Published online: 24 November 2018 www.karger.com/cpb \\
\cline { 2 - 3 }
\end{tabular}}

Zhang et al.: miR-135a and Inflammation

55 Zheng G, Pan ML, Jin WM, Jin GX, Huang YM: MicroRNA-135a is up-regulated and aggravates myocardial depression in sepsis via regulating p38 MAPK/NF-kappa B pathway. Int Immunopharmacol 2017;45:6-12.

-56 Im NK, Jang WJ, Jeong CH, Jeong GS: Delphinidin Suppresses PMA-Induced MMP-9 expression by blocking the NF-kappa B activation through MAPK signaling pathways in MCF-7 human breast carcinoma cells. J Med Food 2017;20:425-425.

-57 Byun EB, Song HY, Mushtaq S, Kim HM, Kang JA, Yang MS, Sung NY, Jang BS, Byun EH: Gamma-Irradiated luteolin inhibits 3-Isobutyl-1-Methylxanthine-induced melanogenesis through the regulation of CREB/ MITF, PI3K/Akt, and ERK pathways in B16BL6 melanoma cells. J Med Food 2017;20:812-819.

$\rightarrow 58$ Lee YC, Cheng CW, Lee HJ, Chu HC: Apple polyphenol suppresses indomethacin-induced gastric damage in experimental animals by lowering oxidative stress status and modulating the MAPK signaling pathway. J Med Food 2017;20:1250-1250.

55 Liu Z, Gan L, Zhou Z, Jin W, Sun C: SOCS3 promotes inflammation and apoptosis via inhibiting JAK2/STAT3 signaling pathway in 3T3-L1 adipocyte. Immunobiology 2015;220:947-953.

60 Zhou XL, Huang L, Cao J: Embelin reduces systemic inflammation and ameliorates organ Injuries in septic rats through downregulating STAT3 and NF-kappa B pathways. Inflammation 2015;38:1556-1562.

61 Purvis HA, Anderson AE, Young DA, Isaacs JD, Hilkens CMU: A negative feedback loop mediated by STAT3 limits human Th17 eesponses. J Immunol 2014;193:1142-1150.

62 Lee HJ, Lee HG, Choi KS, Surh YJ, Na HK: Diallyl trisulfide suppresses dextran sodium sulfate-induced mouse colitis: NF-kappa B and STAT3 as potential targets. Biochem Biophys Res Commun 2013;437:267273.

63 Chen YY, Ma ZB, Xu HY, Shi LJ, Li DY, Sun LY, Yin XH, Sang GY, Xu D, Tang YH, Wang X, Li P, Wu F, Zhou J: IL-6/ STAT3/SOCS3 signaling pathway playing a regulatory role in ulcerative colitis carcinogenesis. Int J Clin Exp Med 2015;8:12009-12017. 